\title{
Adhocracy Culture and Strategy Implementation: An Application within Professional Bodies in Kenya
}

\author{
Anne W. Njagi ${ }^{1}$, Joseph Ngugi Kamau ${ }^{1}$ \& Charity W. Muraguri ${ }^{1}$ \\ ${ }^{1}$ Chandaria Business School, United States International University - Africa, Nairobi, Kenya \\ Correspondence: Anne W. Njagi, Chandaria Business School, United States International University - Africa, \\ Nairobi, Kenya. E-mail: waringanjagi@yahoo.com
}

Received: May 29, 2020

doi:10.5539/ijbm.v15n9p47
Accepted: July 9, 2020

Online Published: August 16, 2020

URL: https://doi.org/10.5539/ijbm.v15n9p47

\begin{abstract}
Strategy implementation presents the most complex aspects of an organization. This study aimed at establishing the relationship between adhocracy culture and strategy implementation in professional bodies in Kenya. To accomplish the main study objective, a descriptive research design was conducted and anchored on Cameron and Quin's theory of Competing Values Framework (CVF) supported by McKinsey 7S Framework. A sampling frame of 168 respondents from 28 active professional bodies registered with the Association of Professional Bodies in East Africa (APSEA) was targeted. Data were collected using a structured questionnaire. Purposive sampling was used to select six (6) top managers in constant touch with the strategy implementation of their organizations. The study tested a null hypothesis and the results were analyzed through regression ANOVA to establish the relationship between adhocracy culture and strategy implementation. From the results, it was found that adhocracy had a significant positive effect on strategy implementation. The study concluded that adhocracy culture and strategy implementation in professional bodies in Kenya have a significant relationship. The study recommends that the leadership of an organization should work to establish a structure that accommodates adhocracy within the organization. Both operational and business level management should be structured in such a way that there is adhocracy culture within the ranks of the organization. The study further recommends a similar survey across the East African region including more professional bodies and further pursuit of adhocracy culture to test its suitability in other organizations other than professional bodies.
\end{abstract}

Keywords: adhocracy culture, creativity, innovativeness, professional bodies, strategy implementation

\section{Introduction}

Spade (2018) argues that corporate strategy can change over time, but organizational culture is very difficult to change once formed. An organizational culture is rigid and facilitates continuity in an organization. It is for this reason that to develop and implement any strategy successfully within an entity, organization culture should be fully aligned. Thus, Organizational management should establish initiatives and goals to support an organizational culture that embraces the organization's strategy in the end. Organizational culture is difficult to change. However, new people entering the organization can influence others to achieve organizational culture change. Spade concluded that culture change can be implemented through conversations about an organization's tendencies and talking about what is working as well as what is not and reflecting on how own behavior can match what an organization desires.

As explained by Wei, Samiee, and Lee (2014), organizational culture is a complicated topic where researchers disagree on its definition, interpretation, and utilization. From an interpretive perspective, culture is viewed as an aspect that an organization is as opposed to something that it has. According to the objectivist argument, culture is viewed from the other end of the spectrum, as a tangible resource that can be transformed and modified to improve the organizational performance. Warrick (2017) argues that the way an individual perceives culture directly influences their beliefs as to whether culture can be transformed. Culture depends on several individual factors, which influence each other. The scholar further states that several of these factors could be controlled while others cannot and the environments exposed to an organization impact its capacity to manage cultural change successfully.

Emre, Faruk, Şentürk, and Ergün (2017) view strategy implementation as a shift of a selected strategy into organizational action to realize targeted goals. It describes the process through which policies and strategies are 
brought into action through programs and procedures. The process of operationalizing plans entails daily decisionmaking particularly for resource allocation (Emre et al., 2017). Strategy implementation is also the point at which the execution of strategic management takes place. It includes aspects of making decisions regarding matching strategy, resources, structure, as well as systems (Reddy, 2017).

Naranjo-Valencia, Jimenez-Jimenez, and Sanz-Valle (2016) posit that a culture of an organization could promote innovation and an organization's performance depending on the values advocated by that culture. An adhocracy culture is suggested as the best predictor of innovation and performance. The decentralization of organizational structure increases the performance of business strategy implementation in any organizational context. Innovation remains an important factor that influences the continuing success of an organization in today's competitive marketplace. Naranjo-Valencia et al. (2016) also observed that today's organizations are highlighting organizational culture as an aspect that can enhance an organization's performance.

As a form of culture practiced in organizations, the term adhocracy comes from the word ad-hoc, which implies that something is temporary, a dynamic unit, or specialized. Similarly, whenever there is an emergency issue that needs to be looked at or investigated, an ad-hoc committee, or task force is formed and when the assignment is complete, they are disbanded immediately (Cameron \& Quinn, 2006). This can fairly be construed to mean adhocracies are temporary just like ad-hoc committees. Again, adhocracies can change quickly when a new set of circumstances arise. It also means that the major aim of adhocracy is to nurture creativity, adaptability, and flexibility when there is uncertainty. Since adhocracy culture is developed out of necessity in the information age just as the way ad-hoc committees are formed, many scholars including Felipe, Roldán, and Leal-Rodríguez (2017) add that the information age is characterized by a rapidly changing and turbulent environment, where the half-life of products is decreasing day by day. Therefore, to keep up with the market, an organization needs to be innovative to produce new quality products as frequently as their previously made products half-life reduces.

It is also notable that Belias and Koustelios (2014) have indicated adhocracy culture to be based on the ability to adjust and adapt rapidly to changing circumstances as they arise. It follows that adhocracy culture is flexible, adjustable, informal, and operates in the opposite of bureaucracy. This culture emphasizes innovation, rapid growth, experimentation, and risk-taking. Lizbetinova and Caha (2016) posit that leaders of organizations with adhocracy culture are risk-takers, visionary, and innovative. The assumption made is that for a company to be successful in the current dynamic environment, it must pioneer innovation initiatives to develop new products and services for the future. Therefore, adaptation, creativity, and innovativeness are assumed to play an important role in making an organization competitive.

Professional bodies are entities with individual members that practice a specific profession or occupation through which the entity or organization maintains ethical oversight to protect the profession's knowledge, skills, conduct, and practices for purposes of integrity and moral society standing (The Science Council, 2018). As much as the professional bodies aim to enhance the status of their specific professions, some do not to adhere to their policies, which is a contravention as pointed out by Wilson (2018). Regular inspection of activities by members of the profession is a routine exercise that helps keep them on top of the profession through Continuous Professional Development (CPD) training, participation in workshops, conferences, and webinars. Governments have also found it more workable to deal with professional bodies. The professional bodies also engage in research and evidence-based findings as noted by Ramphal and Rajcoomar (2018). The scholars also note that professional bodies are now operating professionally, raising the quality of services to the consumers.

Professional certifications or recognitions of specific exams both local and international have also helped cement the status and prestige of these professional bodies. These include such certifications as Certified Public Accountants (CPA) for Kenya's accounting profession, Kenya School of Law certificate for lawyers, and Architectural Certificate for Kenyan architectural professionals among others (Oredo, Njihia \& Iraki, 2017). The professional bodies are usually strict on what certifications and degrees to accept. However, they have always been slow to react whenever one of their members does not comply with the standards set by their bodies (McCowan, 2018). This calls for investigation on the applicability of adhocracy culture in these professional bodies and the way the culture relates to strategy implementation. Strategy, as much as it is planned and implemented requires a set of criteria for success. Whenever implementation takes place, there is always a need to have some form of measurement on the success of strategy (Bridges, 2016). The key success criteria for most organizations consist of suitability, feasibility, and acceptability for a given strategy in an organization.

Organizations assess their engagements and communication as well as the company culture during the implementation of the strategy. By so doing, the organization can tie the objectives to the strategic mission while keeping every step simplified for all to understand in the organization (Anning-Dorson, 2016). In criteria of success, 
there exists a well-maintained database of events, complete, pending, or in progress. This calls for the use of dashboards to enable monitoring of what has been done and what is pending. Even though organizations might differ from one industry to another, the criteria of success are normally uniform in keeping documentation of all completed strategic objectives (Mutai, 2015). For strategy implementation to have a high chance of success, risks must be undertaken all through the planned strategic period. Goals cannot be achieved without taking some risks as without them, there would be no fear of taking on any strategic plan in any organization or economic sector (Felipe et al., 2017).

Adhocracy culture advocates for risks as the nature of its application calls for that mode of operation (Al-Ali, AlNahyan, \& Sohal, 2017). There are clear cases of projects undertaken successfully due to adhocracy culture enabling the risk-taking environment. One such project is the Apollo 11 space mission to the moon in which engineers took high risks to enable man to set foot on the moon without knowing exactly what was beyond the earthly skies (Porcu et al., 2017). The success of risky missions always inspires the rest of the society to continue being innovative while failure could also encourage more risk-takers to even try harder (Abubakar, Elrehail, Alatailat, \& ElçI, 2019). This means risk-taking can both be positive as well as negative.

Strategy implementation calls for heavy investment and risks are involved in doing so. However, in the face of scarce resources, there is a need for creativity to achieve missions as per the strategic plan (Müller \& de Lichtenberg, 2018). The act of turning ideas into reality is what makes strategy visible and more so if the plans are positively implemented. The culture of adhocracy combines risk-taking and creativity to overcome any kind of shortfall on the path towards successful implementation of strategy (Oredo et al., 2017). Common examples of creative ideas in the construction industry include advance purchases of materials at low prices long before their usage is required. This also combines risk-taking behavior that is key in adhocracy to create the missing link in concrete strategy implementation (Spade, 2018).

\subsection{Statement of the Problem}

Strategy implementation has been a difficult goal to achieve throughout many organizations leading to many studies on what exactly can relate positively to a successful implementation. A study by Monahan, Murphy, and Johnson (2016) reported that in many countries including those in Asia, Europe, and the Americas, $47 \%$ of the organizations could not sustain their implementation strategy. Executives in these markets attributed $34 \%$ of the failure of sustaining strategy implementation to the complexity of the operating model, $31 \%$ to the inability of an organization to innovate in a volatile competitive environment, and $28 \%$ to lack of cultural connection (Monahan, Murphy, \& Johnson, 2016). Even though Bridges (2016) reported that the failure rate for strategy implementation was $67 \%$ across organizations including professional bodies, there is still a strong search for influencers of strategy implementation in organizations.

Strategy implementation failure is also common in emerging economies such as Africa. According to a report published by Price Waterhouse Coopers (PWC), in Africa, only a few firms close the gap between their strategy and strategy execution successfully (Boegman, 2016), and only organizations that have capacity and value proposition might bridge the strategy execution gap. Research done in South Sudan (Akuei, Katuse, \& Njenga 2016) and Kenya (Mwangi, 2009) indicate the inadequacy of human and financial resources, lack of stakeholder commitment, inexperience, and organizational culture, as some of the key challenges to strategy implementation. Other researches done in Kenya to assess the challenges of strategy implementation in Kenyan organizations indicated restrictive regulations, complex environment, industry forces, poor organizational structure, and culture (Kipkosgei, 2016), as well as employee skills (Kiplagat, 2014) as major challenges to strategy implementation.

In the recent past, professional bodies in Kenya witnessed strategic failure through the numerous cases of corruption and poor corporate governance, associated with failure in strategy implementation. The Institute of Certified Public Accountants of Kenya (ICPAK), which audits both public and private entities, has pinpointed out fraud and financial mismanagement in public and private institutions, such as Dubai Bank, the Imperial Bank, Mumias Sugar, Uchumi Supermarkets, and Kenya Airways without the five market forces that could naturally necessitate their failure (Muthoga, Odhiambo, Ngugi, \& Ngugi, 2018). Similarly, other professional bodies including Engineering and Architectural as well as the Law Society of Kenya (LSK) and medical practitioners have not been left out for failing to prosecute fake architects, misbehaving lawyers, and quacks in the healthcare sector (Munaita \& Wainaina, 2018). These cases elicit the question, could adhocracy culture perhaps have anything to do with strategy implementation?

\subsection{Theoretical Foundation}

The anchoring theory for this study was the Competing Values Framework (CVF) by Cameron and Quinn (2006). The assessment of organizational culture was based on Organizational Culture Assessment Instrument (OCAI) 
developed by Cameron and Quinn. They postulated that every organization has four competing values where they exist in a blended fashion. The tool makes it possible to determine which culture types are present in an organization. Their position was that organizations do not have a single culture but have a dominant culture. Acar and Acar (2014) support this view by stating that the competing values framework shows that organizational cultures compete against each other.

Cameron and Quinn (2006) noted that adaptable organizations are the most successful because they can change from one culture to another based on trends. The four effective criteria models in CVF are also known as the four organizational culture quadrants.

Cameron and Quinn (2006) referred the four types of culture as clan, adhocracy, market, and hierarchy. In the final four quadrants, the four organizational types are located. The four dimensions of Cameron and Quinn Model are shown in Figure 1.

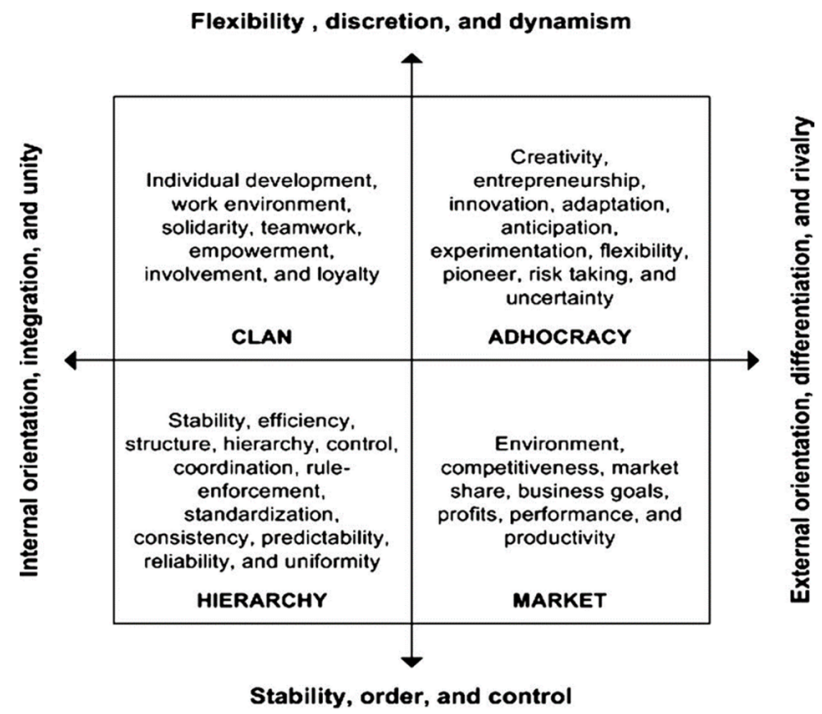

Figure 1. The Four Dimensions of Culture (Cameron \& Quinn, 2006)

The majority of the organizations that adopt adhocracy culture are those involved in businesses such as aerospace, consulting, software development, and filmmaking among others. A common challenge to these kinds of industries is the production of novel products and services to grasp new opportunities (Cameron \& Quinn, 2011). Therefore, due to the high demand for innovation, adhocracies cannot have centralized power like in hierarchies, but rather, power trickles from one person to another or from one task team to another taking cognizance of the issue being addressed. Brännström and Staffansson (2014) emphasize individuality where everyone is involved in the production process, research, and development among other matters. A good example is a consulting firm where each client demand is treated differently from others and taken as an independent project. Thereafter, a temporary plan is set up to complete the client demand and after accomplishing the task the project ends and the task force is disbanded.

\section{Literature Review}

One of the most recognizable examples of adhocracy in the application is the Apollo 13 space mission in which the United States of America was planning to send a man to the moon quickly in rivaling the Russian space projects. During any flight, astronauts and their support staff could not be organized steadily for a long time. This is because of the emergence of a different problem that required different solutions to be addressed. The task team in Apollo 13 during their mission had to change from time to time with the astronauts piloting the space flight shifting from one astronaut to another. According to Cameron and Quinn (2006), in the first 8 years of its existence, the structure of Apollo 13 changed 17 times. During that period, an organization chart could not be drawn because it would be outdated the next day. Policies were temporary and job responsibilities and titles were changing weekly. Organizations working in such circumstances have to adopt adhocracy culture.

Haffar, Al-Karaghouli, and Ghoneim (2014) endeavored to study the impact of all four types of organizational culture on the elements of Individual Readiness for Change (IRFC) regarding Total Quality Management (TQM) implementation, in manufacturing organizations in Syria. The study applied a survey design and administered a questionnaire on 350 manufacturing companies. Findings indicated that individual readiness for change is greatly 
influenced by the type of culture in organizations. The most important goal in the development of organizational cultures is ensuring that the members of the organization are aligned with the requirements of the firm. Haffar et al., further add that businesses that require the adoption of change regularly should develop adhocracy as their preferred culture as it facilitates an easier process of strategy implementation. The creativity and flexibility associated with this type of culture are instrumental in ensuring strategies are implemented accordingly. Essentially, the individual perspective on various tasks and shifts in strategy is contingent on the type of culture that is adopted by a company; hence, leaders should be compelled to develop values that project freedom and inclusiveness on the human assets.

O'Neill, Beauvais, and Scholl (2016) analyzed the association between organizational culture and structure with strategic behavior and performance. Findings showed that an organization with the appropriate culture could fail in the implementation of strategy if the culture does not align with the structure. Adhocracy and a flat structure make a good combination that is linked to a high level of motivation and autonomy in the employees. This combination would be perfect for the implementation of strategies that require the input of every member of the organization. Loyalty is cultivated through this approach and it is apparent that adhocracy is meant for companies with specific leadership and structural orientation. The study further revealed that one of the most important goals in managing organizational strategies is ensuring harmony between its culture and structure. O'Neill et al. also recommended that culture and structure within an organization should oversee the conduct of employees through the reduction of risks and equivocality.

Mutai (2015) conducted a study on the effects of organizational culture at Airtel Kenya. Results indicated that there was success in implementing strategy following a specific culture as adopted by the organization. The findings further showed well-coordinated activities in environments where culture was well founded. Besides, the results revealed that communication is key to any successful strategy implementation and if an organization has none, staff remain speculative and fear to make decisions amounting to difficulties in implementing any strategy. In addition, Mutai (2015) observed a lot of literature about the adhocracy culture in firms' implementation of the strategy. However, the existing literature has scarcely discussed or revealed details about the extent of the influence of this aspect of organizational culture on strategy implementation. It has not covered the aspects of innovativeness in the organization as a factor that would facilitate the effective implementation of strategies. The literature has also not looked at the professional bodies' application of adhocracy culture in their strategy implementation.

\section{Methods}

A descriptive research design was used in the study. A structured questionnaire was used for data collection. The target was 168 respondents from 28 professional bodies registered with the APSEA. The respondents were targeted with a view of their familiarity with strategy implementation in their organizations. To get the respondents in the field, a drop and pick method was used with frequent telephone as well as email follow-ups. Responses from 132 respondents were analyzed using Statistical Package for the Social Sciences (SPSS) version 23. The main analysis used was product-moment regression through ANOVA comparing F calculated value with F-Critical value in testing the null hypothesis (H0): There is no relationship between adhocracy culture and strategy implementation in professional bodies of Kenya.

\section{Results}

\subsection{Regression Model Summary}

The model summary results presented in Table 1 indicate that adhocracy culture explained $5.7 \%$ of strategy implementation in professional bodies in Kenya $\left(\mathrm{R}^{2}\right)=.057$.

Table 1. Model Summary of Adhocracy and Strategy Implementation

\begin{tabular}{|c|c|c|c|c|c|c|c|c|c|}
\hline \multirow[t]{3}{*}{ Model } & \multirow[t]{3}{*}{$\mathrm{R}$} & \multirow[t]{3}{*}{$\mathrm{R}^{2}$} & \multirow[t]{3}{*}{ Adjusted $\mathrm{R}^{2}$} & \multirow{3}{*}{$\begin{array}{l}\text { Std. Error of } \\
\text { the Estimate }\end{array}$} & \multicolumn{5}{|c|}{ Change Statistics } \\
\hline & & & & & Square & F Change & $\mathrm{df}^{1}$ & $\mathrm{df}^{2}$ & Sig. F Change \\
\hline & & & & & \multicolumn{5}{|l|}{ Change } \\
\hline 1 & $.254^{\mathrm{a}}$ & .064 & .057 & .56625 & .064 & 8.946 & 1 & 130 & .003 \\
\hline
\end{tabular}

a. Predictors: (Constant), adhocracy culture

\subsection{Regression ANOVA for Adhocracy}

The regression ANOVA showed that adhocracy culture had a significant influence on strategy implementation $F$ 
$(1,131)=8.946, p<.05)$ as indicated on Table 2 . This means that the regression model was suitable for predicting the outcome variable on how adhocracy culture influenced strategy implementation in professional bodies in Kenya.

Table 2. Regression ANOVA of adhocracy and strategy implementation

\begin{tabular}{lllllll}
\hline Model & & Sum of Squares & df & Mean Square & F & Sig. \\
\hline \multirow{3}{*}{1} & Regression & 2.868 & 1 & 2.868 & 8.946 & $.003^{\text {b }}$ \\
& Residual & 41.682 & 130 & .321 & & \\
& Total & 44.551 & 131 & & & \\
\hline
\end{tabular}

a. Dependent Variable: strategy implementation.

b. Predictors: (Constant), Adhocracy culture.

\subsection{Regression Coefficient on Adhocracy Culture and Strategy Implementation}

Table 3 shows the results of the regression coefficient. In the regression coefficients model, the analysis showed that adhocracy culture statistically predicted strategy implementation. For the adhocracy culture, beta of .254 was statistically significant at $p<.05$. This means, one unit of increase in adhocracy culture, increased the unit of strategy implementation by .254 .

Table 3. Coefficients of adhocracy and strategy implementation

\begin{tabular}{|c|c|c|c|c|c|c|}
\hline \multirow[t]{2}{*}{ Model } & & \multicolumn{2}{|c|}{ Unstandardized Coefficients } & \multirow{2}{*}{$\begin{array}{l}\text { Standardized } \\
\text { Coefficients } \\
\text { Beta }\end{array}$} & \multirow[t]{2}{*}{$\mathrm{t}$} & \multirow[t]{2}{*}{ Sig. } \\
\hline & & B & Std. Error & & & \\
\hline \multirow{2}{*}{1} & (Constant) & 2.386 & .442 & & 5.403 & .000 \\
\hline & Adhocracy culture & .338 & .113 & .254 & 2.991 & .003 \\
\hline
\end{tabular}

a. Dependent Variable: strategy implementation

From the coefficient table, the values of the regression model were derived:

The general form of the regression model used was:

$$
Y=\beta_{0}+\beta_{1} X_{1}+\varepsilon
$$

$\beta_{0}=$ Constant $; \beta_{1}=$ Adhocracy culture and $\varepsilon=$ Error term

Thus from the coefficient table, adhocracy culture influenced strategy implementation in professional bodies in Kenya

$$
\mathrm{Y}=2.386+.254 \mathrm{X}_{1}+.113
$$

The linear regression analysis was used to test if adhocracy culture significantly predicted strategy implementation among employees in professional bodies in Kenya. Thus, the null hypothesis that "there is no relationship between adhocracy culture and strategy implementation in professional bodies in Kenya" was rejected.

\section{Discussion}

Many scholars including Willar, Trigunarsyah, and Coffey (2016) have previously indicated that the implementation of planned strategy can be associated with the adhocracy culture in an organization. The scholars argue that the informal setups in the adhocracy environment enable the sharing of ideas freely, which gives a high chance of having a strategy implemented.

Similarly, when an organization's environment provides harmony between its structure and the culture, there is a high possibility of success in strategy implementation. This clearly supports the relationship existing between adhocracy culture and strategy implementation. Other scholars that support the relationship between adhocracy culture and strategy implementation include O'Neill et al., (2016) who concluded that adhocracy and a flat structure contribute to a high level of motivation and autonomy in an organization leading to the successful implementation of a strategy by that organization. 
In another study, Haffar, Al-Karaghouli, and Ghoneim (2014) concluded that creativity and flexibility that comes with adhocracy is a very ripe environment for strategy implementation, specifically in organizations that emphasize inclusiveness. The aspects of coordination and association also play a strong role in bringing together people of various backgrounds as pointed out by O'Neill et al., (2016). These two are clearly linked to adhocracy culture and hence leading to success in the implementation of strategy.

Cameron and Quinn (2006) have clearly advocated for the adhocracy culture arguing that the ad-hoc committees that are formed through adhocracy give an environment of positive strategy implementation arguing that any new arising circumstances would be well handled with yet another well-composed ad-hoc team. These two scholars cite the famous Apollo missions to the moon as an example in which the various impromptu and planned changes in the complex project heavily applied adhocracy culture to achieve near-impossible results of landing on the moon. On the contrary, Abubakar et al. (2019) have shown that there is mixed or inconclusive evidence to show how culture in particular adhocracy supports the implementation of strategy. In fact, the scholars dispute any relationship between the implementation of strategy and adhocracy culture. Their views and findings are also supported by O'Neill et al., (2016) who contend that there can only be specific traits of adhocracy that can support strategy implementation but not all. In particular, they point to flat structures without which, the success of strategy implementation cannot happen.

Earlier, Akuei et al. (2016) disputed the claim that adhocracy culture can solely influence the implementation of strategy arguing that in various regions, many cultures would not survive and this would result in complete failure of strategy implementation. Their argument is that corporate culture more than the adhocracy culture would be more suitable as a determinant of the success of strategy implementation. This is also supported by Al-Ali et al., (2017) who found that there existed little reference to the implementation of strategy over various adhocracy cultures. In effect, the scholars stated that other factors other than the adhocracy culture were at play in determining the success of strategy implementation. More evidence from Anning-Dorson (2017) indicates that adhocracy culture is not so dominant in the implementation of strategy specifically pointing to hierarchy culture as being more decisive in the influence of strategy implementation. The scholar also points to the type of organization in which various entities could have a specific culture enhancing their strategy implementation as opposed to others. In other words, adhocracy culture is not a sweeping success in the implementation of the strategy.

In theoretical terms, Pearce (2016) points out that lack of clear leadership exists in an adhocracy environment leading to serious but silent organization fights that are detrimental to strategy implementation. This is manifested in the lack of proper competency frameworks that could indicate the direction of a strategy to be implemented leading to the slowing down of the very implementation process that is sought by the organization. Other critics of the adhocracy that oppose any relationship between the adhocracy culture and strategy implementation include Porcu, del Barrio-García, Alcántara-Pilar, and Crespo-Almendros (2017). The scholars concluded that there is difficulty in diagnosing and assessing the changes taking place in an organization if adhocracy is the key type of culture.

Other scholars against the adoption of adhocracy culture include Muller and de Lichetenberg (2018) who observed that with adhocracy, organizational members tend not to be enthusiastic about the on goings since it would appear that there is no strict plan in place to be followed by the organization. This then leads to organization members not being aware of what to do next and hence not ready for implementation of long-term strategies. As witnessed in many projects, the tendency to have adhocracy arises from the need to implement plans that simply must be completed. The professional field in many economic sectors in Kenya has always required project completion either over a very short period or under tight timelines. This then, calls for the application of adhocracy culture within the various sectors. In fact, the professional bodies operate in a manner that dictates that any of their members can be called upon to carry out an assignment on their professional line successfully. For instance, any lawyer within the LSK can be called upon to represent a client anywhere in Kenya. Similarly, any accounting duties can be easily undertaken by any member of ICPAK in an ad-hoc manner.

\section{Conclusion}

The study concluded that adhocracy culture and strategy implementation in professional bodies in Kenya are significantly related. Based on this, the effect of adhocracy in the organization cannot be overlooked leading to the recommendation that the leadership of an organization should work to establish a structure that accommodates adhocracy in that organization. Both operational and business level management should be structured in such a way that there is adhocracy culture within the ranks of the organization.

The study recommends that organization leadership should be structured around adhocracy culture. A good practice would require that top managers engage their staff for specific periods during strategy implementation in 
order to test adhocracy. Regardless of whether it works for a particular sector or not, good leaders should have the right people who can implement plans in ad-hoc manner. This, therefore, calls for team leaders to empower staff at all levels to handle various activities from time to time in an adhocracy manner.

\section{Acknowledgement}

I sincerely thank my mentors Dr. Joseph Ngugi and Dr. Charity W. Muraguri for the guidance in research writing.

\section{References}

Abubakar, A. M., Elrehail, H., Alatailat, M. A., \& Elçi, A. (2019). Knowledge management, decision-making style, and organizational performance. Journal of Innovation and Knowledge, 4(2), 104-114. https://doi.org/10.1016/j.jik.2017.07.003

Acar, A. Z., \& Acar, P. (2014). Organizational culture types and their effects on organizational performance in Turkish hospitals. EMAJ: Emerging Markets Journal, 3(3), 18-31. https://doi.org/10.5195/emaj.2014.47

Akuei, A. M., Katuse, P., \& Njenga, K. (2016). The role of organization culture on effective strategy the role of organization culture on effective strategy. The International Journal of Business \& Management, 4(6), 391394. http://erepo.usiu.ac.ke/11732/2329

Al-Ali, A. A., Singh, S. K., Al-Nahyan, M., \& Sohal, A. S. (2017). Change management through leadership: The mediating role of organizational culture. International Journal of Organizational Analysis, 25(4), 723-739. https://doi.org/10.1108/IJOA-01-2017-1117

Anning-Dorson, T. (2017). Moderation-mediation effect of market demand and organization culture on innovation and performance relationship. Marketing Intelligence and Planning, 35(2), 222-242. https://doi.org/10.1108/MIP-04-2016-0066

Belias, D., \& Koustelios, A. (2014). Organizational culture and job satisfaction: A review. International Review $\begin{array}{llll}\text { of Management and } & \text { Marketing, }\end{array}$ https://www.econjournals.com/index.php/irmm/article/view/746

Boegman, H. (2016). Africa business report, seeing the glass half-full. PwC Africa Business Agenda. https://www.pwc.co.za/en/assets/pdf/africa-business-agenda-2016.pdf

Brännström, H., \& Staffansson, F. (2014). The prominence of organizational culture in workplace well: A qualitative research on an international organization. SE-901 87 Umea Sweden: Umeå School of Business and Economics, Umeå University. Retrieved from https://www.divaportal.org/smash/get/diva2:740636/FULLTEXT01.pdf

Bridges, R. (2016). We still don't know the difference between change and transformation. Harvard Business Review. Retrieved from https://hbr.org/2015/01/we-still-dont-know-the-difference-between-change-andtransformation.

Cameron, K., \& Quinn, R. E. (2011). Diagnosing and changing organizational culture: Based on the competing values framework (2nd ed.). New York: Wiley.

Cameron, K., \& Quinn, R. E. (2006). Diagnosing and changing organizational culture: Based on the competing values framework. Beijing: China Renmin University Press.

Emre, Y., Faruk, T., Şentürk, K., \& Ergün, E. (2017). Corporate culture and business strategy: Which strategies can be applied more easily in which culture? International Journal of Business and Social Science, 8(6), 8091. https://ijbssnet.com/journals/Vol_8_No_6_June_2017/9.pdf

Felipe, C. M., Roldán, J. L., \& Leal-Rodríguez, A. L. (2017). Impact of organizational culture values on organizational agility. Sustainability (Switzerland), 9(12). https://doi.org/10.3390/su9122354

Haffar, M., Al-Karaghouli, W., \& Ghoneim, A. (2014). An empirical investigation of the influence of organizational culture on individual readiness for change in Syrian manufacturing organizations. Journal of Organizational Change Management, 27(1), 5-22. https://doi.org/10.1108/JOCM-04-2012-0046

Kipkosgei, K. J. (2016). Challenges of strategy implementation in the national government ministries in Kenya (Master's thesis, University of Nairobi, Kenya). Retrieved from http://erepository.uonbi.ac.ke/bitstream/handle/11295/10756/Magambo_Challenges\%20Of\%20Strategy\%20 Implementation\%20In\%20Public\%20Corporations\%20In\%20Kenya.pdf? sequence $=3 \&$ isAllowed $=\mathrm{y}$

Kiplagat, V. (2014). Strategy implementation challenges in government parastatals: A case of Kenya Revenue Authority (Master's thesis, United States International University Africa, Nairobi). Retrieved from 
http://erepo.usiu.ac.ke/11732/150

Ližbetinová, L., Lorincová, S., \& Caha, Z. (2016). The application of the Organizational Culture Assessment Instrument (OCAI) to logistics enterprises. Nase More, 63(3), 170-176. https://doi.org/10.17818/NM/2016/SI17

McCowan, T. (2018). Quality of higher education in Kenya: Addressing the conundrum. International Journal of Educational Development, 60, 128-137. https://doi.org/10.1016/j.ijedudev.2017.11.002

Miles, M. B., Huberman, M. A., \& Saldana, J. (2014). Qualitative data analysis: A methods sourcebook (3rd ed.). London: Sage Publications.

Monahan, K., Murphy, T., \& Johnson, M. (2016). Humanizing change. Deloitte. Retrieved from https://dupress.deloitte.com/content/dam/dup-us-en/articles/developing-more-effective-changemanagement-strategies/DR19_HumanizingStrategy.pdf.

Müller, S. D., \& de Lichtenberg, C. G. (2018). The culture of ITIL: Values and implementation challenges. Information Systems Management, 35(1), 49-61. https://doi.org/10.1080/10580530.2017.1416946

Munaita, P., \& Wainaina, E. (2018). How Mugo got his dirty job back after a short stay in Kenyan prison. Daily Nation. Retrieved from https://www.nation.co.ke/kenya/news/how-mugo-got-his-dirty-job-back-after-shortstay-in-prison-106450

Mutai, P. K. (2015). Organizational culture and strategy implementation at Airtel Kenya (Master's thesis, University of Nairobi, Kenya). Retrieved from http://hdl.handle.net/11295/93560

Muthoga, N., Odhiambo, R., Ngugi, P. K., \& Ngugi, J. K. (2018). Influence of competitive aggressiveness on microinsurance uptake by micro and small enterprises in Kenya. International Journal of Strategic Management 7(3), 1-25. https://www.ijsse.org/images/ijsm_v7_i3_1_25.pdf

Mwangi, L. N. (2009). Challenges facing implementation of strategic plan at Blueshield insurance company limited (Master's thesis, University of Nairobi, Kenya). Retrieved from http://erepository.uonbi.ac.ke:8080/xmlui/handle/123456789/13419

Naranjo-Valencia, J. C., Jiménez-Jiménez, D., \& Sanz-Valle, R. (2016). Studying the links between organizational culture, innovation, and performance in Spanish companies. Revista Latinoamericana de Psicologia, 48(1), 30-41. https://doi.org/10.1016/j.rlp.2015.09.009

O’Neil, J. W., Beauvais, L. L., \& Scholl, R. W. (2016). The use of organizational culture and structure to guide strategic behavior: An information processing perspective. Journal of Behavioral and Applied Management, 2(2), 816. https://jbam.scholasticahq.com/article/816-the-use-of-organizational-culture-and-structure-toguide-strategic-behavior-an-information-processing-perspective

Oredo, J., Njihia, J., \& Iraki, X. N. (2017). The role of organizing vision in cloud computing adoption by organizations in Kenya. American Journal of Information Systems, 5(1), 38-50. https://oi.org/10.12691/ajis5-1-6

Pearce, A. (2016). Internationalisation strategy implemented through faculty exchange: Strategic entrepreneurship in a "new" United Kingdom University. International Journal of Business Innovation \& Research, 10(1), 4364. https://doi.org/10.1504/IJBIR.2016.073243

Porcu, L., Barrio-García, S. D., Alcántara-Pilar, J. M., \& Crespo-Almendros, E. (2017). Examining the mediating role of integrated marketing communication on the relationship between adhocracy culture and brand advantage. In G. Christodoulides, A. Stathopoulou, \& M. Eisend, Advances in advertising research (Vol. VII): Bridging the gap between advertising academia and practice (pp. 281-295). Wiesbaden: Springer Gabler. https://doi.org/10.1007/978-3-658-15220-8_20

Ramphal, R., \& Rajcoomar, A. (2019). A framework for the management of professional bodies in South Africa. The Social Sciences, 14(1), 29-38. https://doi.org/10.36478/sscience.2019.29.38

Reddy, M. (2017). The effect of organisational culture on strategy execution (Doctoral dissertation, University of Pretoria). Retrieved from http://hdl.handle.net/2263/59757

Saunders, M., Lewis, P., \& Thornhill, A. (2016). Research methods for business students (Seventh ed.). Harlow: Pearson.

Spade, D. (2018). Organizational culture chart. Retrieved from http://www.deanspade.net/2018/12/18/what-it-islike-inside-our-organizations/ 
The Science Council. (2018). Our definition of a professional body. Retrieved from https://sciencecouncil.org/about-science/our-definition-of-a-professional-body/

Warrick, D. D. (2017). What leaders need to know about organizational culture? Business Horizons, 60(3), 395404. https://doi.org/10.1016/j.bushor.2017.01.011

Wei, Y. S., Samiee, S., \& Lee, R. P. (2014). The influence of organic organizational cultures, market responsiveness, and product strategy on firm performance in an emerging market. Journal of the Academy of Marketing Science, 42(1), 49-70. https://doi.org/10.1007/s11747-013-0337-6

Willar, D., Trigunarsyah, B., \& Coffey, V. (2016). Organizational culture and quality management system implementation in Indonesian construction companies. Engineering, Construction and Architectural Management, 23(2), 114-133. https://doi.org/10.1108/ECAM-02-2015-0026

Wilson, C. (2018). UK professional bodies sign and publish evidence declaration. British Dental Journal, 224(1), 6. https://doi.org/10.1038/sj.bdj.2018.17

\section{Copyrights}

Copyright for this article is retained by the author(s), with first publication rights granted to the journal.

This is an open-access article distributed under the terms and conditions of the Creative Commons Attribution license (http://creativecommons.org/licenses/by/4.0/). 